\title{
裸眼立体映像システムにおける オブジェクトの切り抜きと見え方の操作
}

\section{Extraction and Viewing Parameter Control of Objects in a 3D TV System}

\author{
永塚遼，＼cjkstart田口裕一计，正会員苗村健 ${ }^{\dagger}$
}

Ryo Nagatsuka $^{\dagger}$, Yuichi Taguchi ${ }^{\dagger \dagger}$ and Takeshi Naemura ${ }^{\dagger \dagger}$

\begin{abstract}
A method of controlling the viewing condition of each object in a 3D TV system consisting of a camera array and an integral photography display is presented. The method allows users to easily extract objects in the input multi-view images, and to independently control the positions of the extracted objects on the display by using different rendering parameters for different objects. It enables interactive editing of 3D scenes such as emphasizing the depth of a certain object and changing the relative positions of objects, rather than presenting the captured scene as it is.
\end{abstract}

キーワード : カメラアレイ, インテグラルフォトグラフィディスプレイ, 光線空間変換, 自由視点画像合成, セグメンテーション

\section{1.まえがき}

3 次元視覚情報を取得するため，カメラを格子状に配列 したカメラアレイが多く開発されている ${ }^{1)}$.これにより取 得したシーンの多視点画像を用いて，そのシーンを自由な 視点位置から見た画像（自由視点画像）を合成する手法が 検討されている.

また， 3 次元視覚情報の再生デバイスとして，裸眼立体 視ディスプレイの研究開発が進んでいる ${ }^{2)}$. 裸眼立体視ディ スプレイでは，異なる視点位置からの映像を異なる方向に 提示することにより，特殊なメガネを必要とせずに 3 次元 映像を表示することができる.

我々のグループでは，カメラアレイにより取得した多視 点画像群から, 自由視点画像合成を用いて変換した画像群 をインテグラルフォトグラフィ(Integral Photography, IP) ディスプレイに立体映像として実時間で提示する裸眼立体 ライブ映像システムを開発している ${ }^{3) \sim 5)}$. IP ディスプレイ においては，高い周波数で再生できる奥行きの範囲が限ら れているため ${ }^{6) 7)}$, 自由視点画像合成時のパラメータを制

2009 年 3 月 31 日受付, 2009 年 6 月 30 日再受付, 2009 年 7 月 27 日採録 †東京大学 工学部

( $=113-8656$ 文京区本郷 7-3-1 TEL 03-5841-6781) 十七東京大学大学院情報理工学系研究科

(T 113-8656 文京区本郷 7-3-1 TEL 03-5841-6781)

$\dagger$ Faculty of Engineering, The University of Tokyo

(7-3-1, Hongo, Bunkyo-ku, Tokyo, 113-8656, Japan)

$\dagger \dagger$ Graduate School of Information Science and Technology, The University of Tokyo

(7-3-1, Hongo, Bunkyo-ku, Tokyo, 113-8656, Japan)
御することにより，シーンのどの部分がディスプレイ上で 鮮明に再生されるかを指定する.

上記のシステムを含め，既存の裸眼立体映像システム ${ }^{8) 9)}$ は，シーンの 3 次元情報をありのままに表示することを目 的としていた。一方，本稿では，オブジェクトの奥行き感 を強調するなどのシーンの編集を目的として，オブジェク トごとに見え方の操作を行う手法を提案する。提案手法で は，多視点画像上でオブジェクトの切り抜きを行った後，才 ブジェクトごとに独立したパラメータを用いて，ディスプ レイに提示する画像を合成する。これを実現するため，(1) 多視点画像からオブジェクトを一括して切り抜くためのイ ンターフェースと, (2) シーン全体ではなくオブジェクト に特化した画像合成手法の提案を行う。評価実験では，才 ブジェクトの奥行きの強調や，オブジェクトの前後関係の 逆転などの効果を IPデイスプレイ上で確認する.

\section{2. 裸眼立体映像システム TransCAIP}

本研究で用いる裸眼立体映像システム TransCAIP ${ }^{3) \sim 5)}$ は，人力として 64 眼のネットワークカメラアレイ 10)を， 出力としての 60 視点 IP ディスプレイ ${ }^{11}$ ) を用いる（図 1). ここでは，TransCAIP システムにおける，IPディスプレ イに表示するための 60 視点画像の合成手法と，パラメー タ制御によるデイスプレイ上での見え方の操作について説 明する。

\subsection{0 視点画像の合成}

カメラアレイによって取得した 64 視点分の画像を入力 として，IPディスプレイに表示寸るための 60 視点分の画 


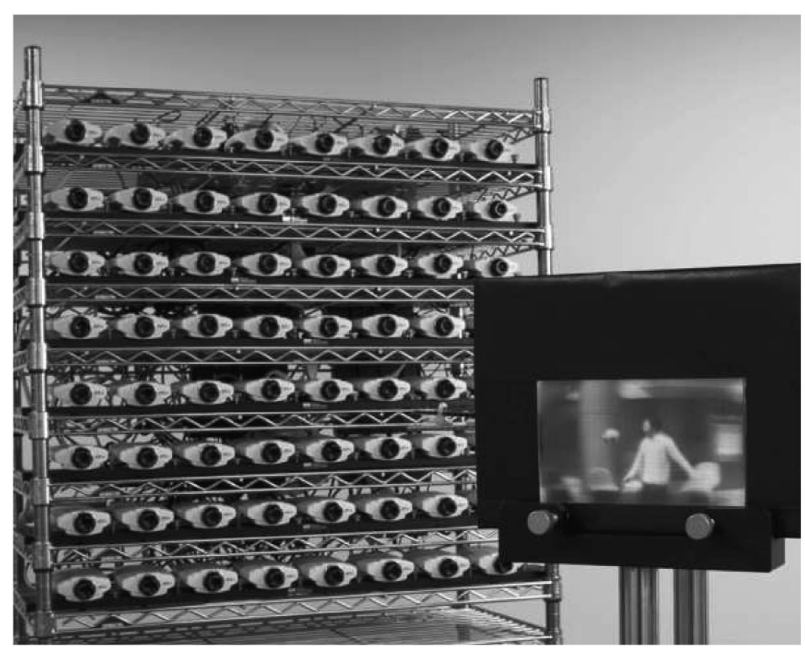

図 164 眼カメラアレイと IP ディスプレイ ${ }^{3) \sim 5)}$ The 64-camera array and IP display ${ }^{3) \sim 5)}$.

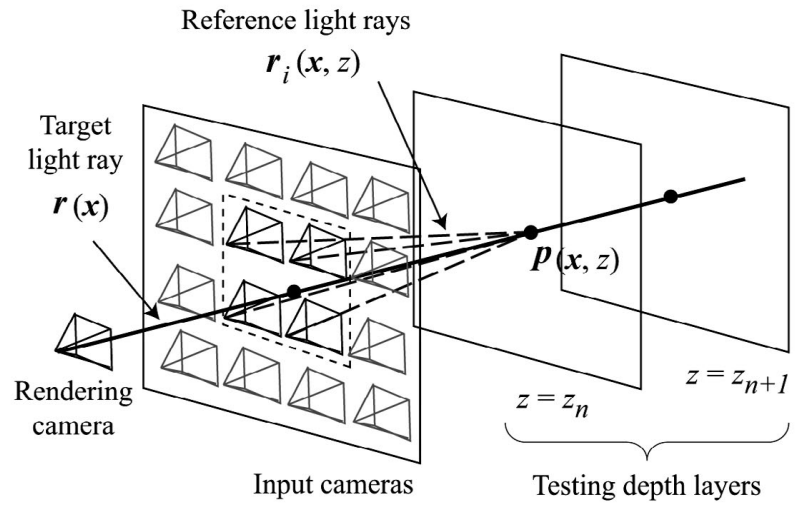

図 2 奥行きレイヤモデル

Layered depth model for synthesizing a desired view.

像を自由視点画像合成手法を用いて生成する. 画像合成手 法は文献 10)のものを用いる。この手法では, 図 2 のよう に, カメラ平面と平行に奥行きレイヤを配置し, 合成画像 上での画素単位の奥行きを視点位置に応じて推定する。こ れは, 図 2 において, すべての target light $\operatorname{ray}(\boldsymbol{r}(\boldsymbol{x}))$ に 刘して最適な奥行き $z$ を割り当てることに相当する.ここ では, target light rayに近接する 4 台のカメラにおける reference light ray $\left(\boldsymbol{r}_{i}(\boldsymbol{x}, z)\right)$ を参照してコストを評価する. この reference light ray は, 各奥行きレイヤと target light ray の交点 $\boldsymbol{p}(\boldsymbol{x}, z)$ を参照カメラ $i$ に射影寸ることにより求 められる. コストは以下の式で与えられる.

$$
C(\boldsymbol{x}, z)=\operatorname{var}\left(\left.I\left(\boldsymbol{r}_{i}(\boldsymbol{x}, z)\right)\right|_{i \in V}\right)
$$

ここで $V$ は参照されるカメラ番号の組であり， $|V|=4$ で ある。またvar は reference light ray の RGB 各色の分散 の和を計算する関数である。このコストは奥行きレイヤご とに平滑化され, 最後に最小值探索を行い, 各 target light ray に対して最適な奥行き $z_{o p t}(\boldsymbol{x})$ を割り当てる. 色の補 間は, 最適な奥行きにおける reference light ray の色の双 線形補間により，以下のように求める.

$$
I(\boldsymbol{r}(\boldsymbol{x}))=\sum_{i \in V} w_{i}(\boldsymbol{x}) I\left(\boldsymbol{r}_{i}\left(\boldsymbol{x}, z_{\text {opt }}(\boldsymbol{x})\right)\right)
$$

ここで $w_{i}(\boldsymbol{x})$ は, 参照カメラ $i$ の reference light ray に対 する重みであり, target light ray と参照カメラの位置が 近いほど, 線形的に増加寸る. また, $\sum_{i \in V} w_{i}(\boldsymbol{x})=1$ で ある、

以上の計算はすべて GPU 上で実行され，出力される合 成画像は GPU のテクスチャメモリーに保存される，合成 された 60 視点分の画像の画素を GPU 上で並べ替えること により, ディスプレイに提示するIP 画像を生成する.

\section{2 インタラクティブな 3 次元映像操作}

TransCAIP システムでは, 画像合成を行うカメラ（レ ンダリングカメラ）のパラメータを操作することにより， 3 次元映像の見え方のインタラクティブ操作を実現している. IP ディスプレイでは, ディスプレイ面上の像が最も高い周 波数で再生され，像の 3 次元位置がディスプレイ面から離 れるに従って，再生可能な周波数が低下する（つまり，鮮明 に再生できる奥行きの範团が限られている） ${ }^{6) 7)}$. このため, TransCAIP システムでは, 図 3 のように, レンダリング カメラの輻輳の位置（輻輳面）を変えることにより，ディ スプレイ面上に再生される奥行きを指定する，輻輳面上の オブジェクトはディスプレイ面上に最も高い周波数で再生 され，それより奥・手前にあるオブジェクトはIPディスプ レイでも奥・手前に，ディスプレイ面上よりも低い周波数 で再生される.

また， 60 視点画像合成時のレンダリングカメラの間隔を 調整することにより，ディスプレイ上での奥行き方向の飛 び出し量を増減することができる．カメラ間隔を狭くした 場合には再生される 3 次元映像の飛び出し量が小さくなり， 広くした場合には飛び出し量が大きくなる，ただし，大き く飛び出したオブジェクトは低い周波数で再生されること に注意が必要である.

\section{3. 提 案 手 法}

以上で述べたように, 従来のシステムでは, 取得した 64 視点画像から 60 視点の自由視点画像合成を行う際に, シー ン全体を一つのパラメータで制御し, 輻輳面や飛び出し量 の調整を行っている. 一方, 本稿で提案する手法は, オブ ジェクトの奥行き感を强調するなどのシーンの編集を目的 として，オブジェクトごとに見え方の操作を行う. 従来手 法と提案手法のフローチャートを図 4 にまとめる. このよ らな操作を実現するための，(1) 多視点画像からオブジェク 卜を一括して切り拔くためのインタフェースと，(2) シー ン全体ではなくオブジェクトに特化した画像合成手法につ いて以下で説明する.

従来のシステムでは, カメラアレイによる多視点画像の 撮影から IP ディスプレイへの提示までを実時間で行うと いう特徴があった。一方, 提案手法では静止画を対象とし, オブジェクトの切り抜きはオフラインで実行する. しかし， 


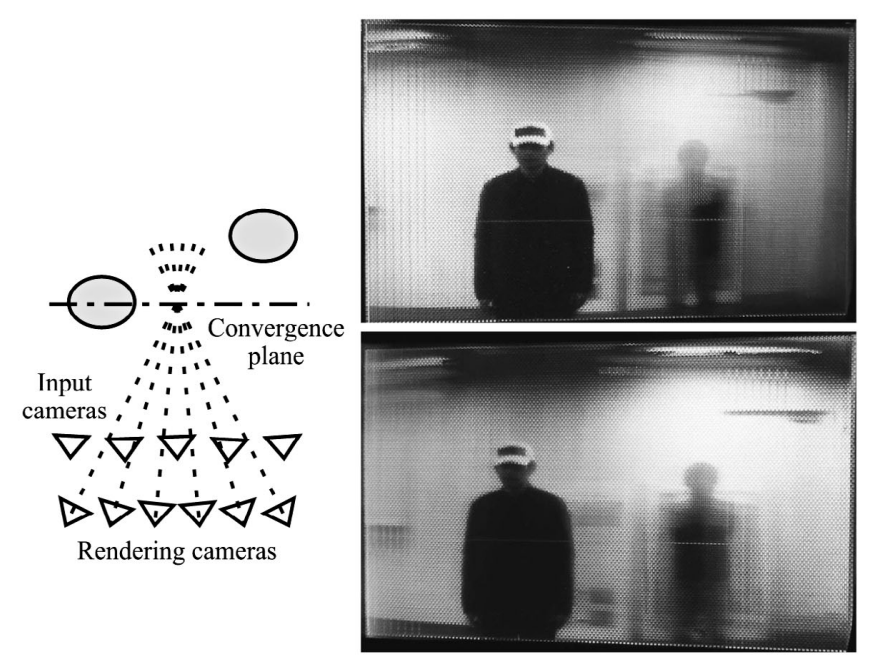

(a) Convergence plane set at the left (near) person

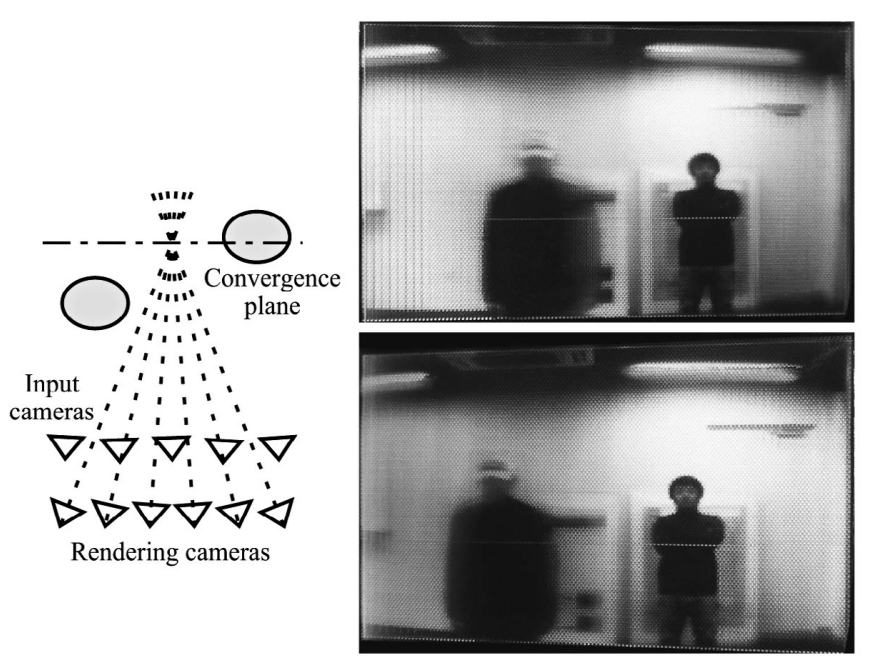

(b) Convergence plane set at the right (far) person

図 33 次元映像の見え方のインタラクティブな操作 ${ }^{3) ~ 5)}$. 指定された輻輳面（左）とIP ディスプレイ上での表示 を右から撮影（上），左から撮影（下）した結果.

Interactive control of viewing parameters ${ }^{3) \sim 5}$ ). The position of convergence plane (left). Displayed results captured from a left (top) and right (bottom) viewpoint.

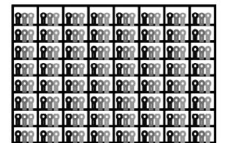

64 input views

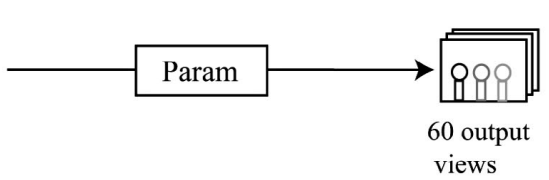

(a) Conventional method

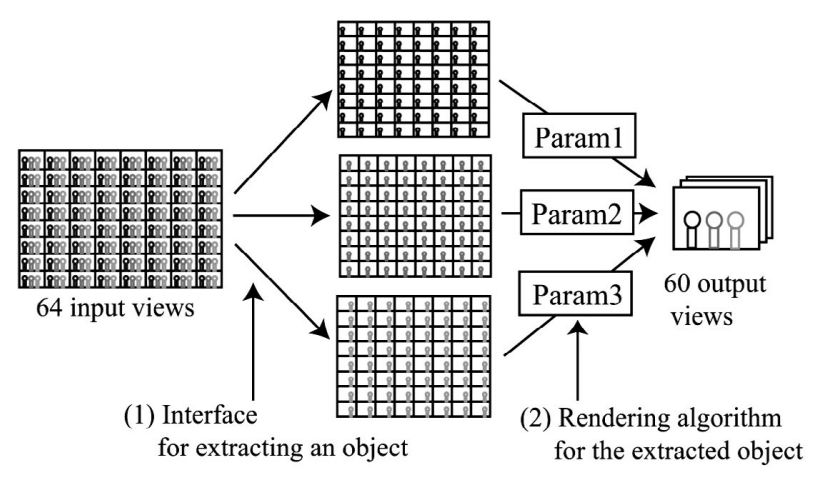

(b) Proposed method

図 4 従来手法と提案手法

Conventional method and proposed method.

オブジェクトごとの画像合成は実時問で実行可能なため, 見 え方の操作はインタラクティブに行うことができる.

\subsection{4 視点画像上の同一のオブジェクトの切り抜き}

オブジェクトごとの独立操作を実現するために，まずオ ブジェクトごとに切り抜いた 64 視点画像を用意する。一 般的な画像から簡易にオブジェクトを切り抜く手法として, 前景と背景の一部分をユーザが seed として指定し，これを 制約としたエネルギー最適化問題をグラフカットを用いて 解く手法がよく利用されている ${ }^{12)}$ 。しかし，64 視点画像 全てに対してユーザが個別に seed を与え，オブジェクトの 切り抜きを行うのは効率的でない. そこで, 64 視点画像か ら自由視点画像を合成し，その画像上でオブジェクトを指 定することにより, 元の 64 視点画像上のオブジェクトを一

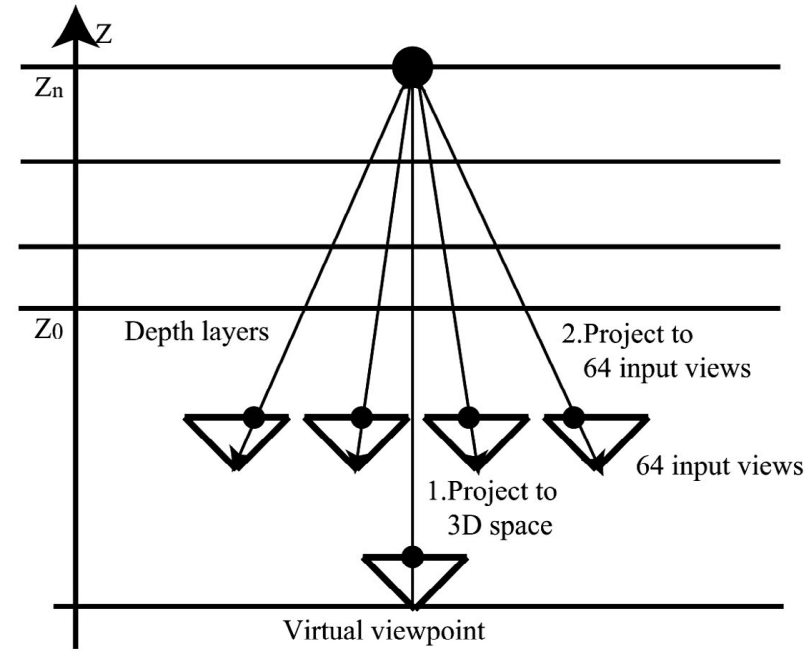

図 5 自由視点画像から 64 視点画像一の点の投影 Projection from a free-viewpoint image to the 64 input images.

括して指定できるインタフェースを提案する.

これを行うために，まず自由視点画像上で指定された点 に対応する 64 視点画像上での点を求める方法について説 明する． 2.1 節で述べたように, 我々が利用する手法は画 像合成時に画素ごとの奥行きを求めている．その奥行きの 值を利用することにより, 自由視点画像上の点と 64 視点 画像上の点との対応を取ることができる，具体的には図 5 のように, 指定した点の画像中の $\mathrm{x}, \mathrm{y}$ 座標, およびその点 の奥行きから，指定した点をオブジェクト座標に変換する. その後, キャリブレーションの結果により求まっている 64 個のカメラの射影行列を用いて, オブジェクト座標から各 入力視点画像へ座標変換を行う.

提案するインタフェースでは, 64 視点画像（図 6(a)）と それから合成された自由視点画像（図 6(b)）を同時に表示 
し, ユーザは自由視点画像上で seed の指定を行う. 具体的 な操作としては, まず $[\mathrm{f}]$ キーを押してから, 自由視点画像 上で切り抜きたいオブジェクト内の点をマウスでドラッグ 寸る. 次に $[\mathrm{b}]$ キーを押してから, 背景に対応寸る点（切 り抜きたいオブジェクト以外のオブジェクトも含む）をド ラッグする.このようにして指定された自由視点画像上で の前景と背景の seed を, 上で述べた方法により 64 視点画 像上での seed に変換する.

前景画像の切り拔きは，64 視点画像それぞれに対する前 景と背景の seed 用いて, 文献 12)の手法により, それぞ れの画像に対して独立に行う。前景画像と一緒にマスク画 像も保存しておき, 後の IP ディスプレイ用の画像を合成 する際に使用する.

オブジェクトの切り抜きを行う際, オクルージョンや推 定された奥行き值のエラーの影響により，視点によっては 与える seed が意図したものとは異なり，うまく切り抜けな いものもある.この場合には，うまく切り抜けなかった画 像に対して個別に前景, 背景の seed を与え直してオブジェ クトを切り抜くこととした.

\section{2 各オブジェクトに対する画像合成手法}

切り抜いたオブジェクトに対して画像合成を行い，IP 画 像を生成する. この際, 奥行き推定の手法が問題となる. 2.1 節で述べた手法では, 近傍四つのカメラから得られる 画素值の分散が最小となるところを正しい奥行き值として いた。しかしこの手法では，オブジェクトの境界付近にお いては, 奥行きレイヤによって参照光線数が一定でないた め, 正しい奥行き推定を行うことができない，そこで，提 案手法では次の式でコストを評価する.

$$
C(\boldsymbol{x}, z)=\operatorname{var}\left(\left.I\left(\boldsymbol{r}_{i}(\boldsymbol{x}, z)\right)\right|_{i \in V^{\prime}}\right)+\left(4-\left|V^{\prime}\right|\right) \cdot P
$$

ここで $V^{\prime}$ は $V$ の中でオブジェクトを通過した光線を含む カメラ番号の組であり， $0 \leqq\left|V^{\prime}\right| \leqq|V|=4$ である. 第 1 項では, オブジェクトを通過した光線のみで分散を計算し, 第 2 項では, オブジェクトを通過しなかった光線がある場 合に，その分だけ $P$ をコストに加えている．Pの值を大き くするほど，オブジェクトを通過しない光線がある奥行き 值は採用されにくくなる.

色の補間方法は，オブジェクトを通過しない光線を考慮 しないようにするため, 式 (2) を

$$
I\left(\boldsymbol{r}_{i}(\boldsymbol{x}, z)\right)=\frac{\sum_{i \in V^{\prime}} w_{i}(\boldsymbol{x}) I\left(\boldsymbol{r}_{i}\left(\boldsymbol{x}, z_{\text {opt }}(\boldsymbol{x})\right)\right)}{\sum_{i \in V^{\prime}} w_{i}(\boldsymbol{x})}
$$

とし，オブジェクトを通過する光線の重みを増加させる．ま た, オブジェクトの有無の判定は, 切り抜きの際に作成し たオブジェクトごとのマスク画像を使用する.

各オブジェクトに対して, レンダリングカメラの輻軞面 や間隔, 視点位置などのパラメータを決定し, 上記の画像 合成手法でIPディスプレイ用の多視点画像を生成する. そ の後, 各オブジェクトに対して合成された IP ディスプレイ

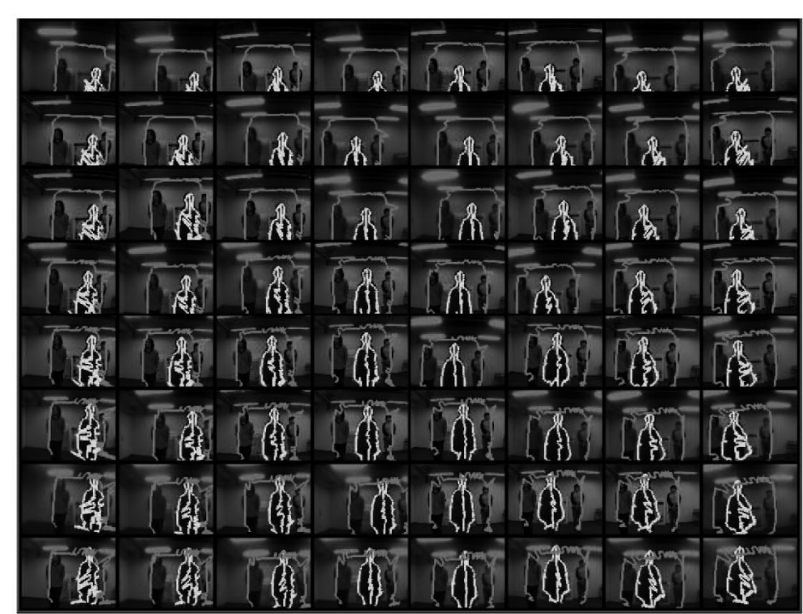

(a)

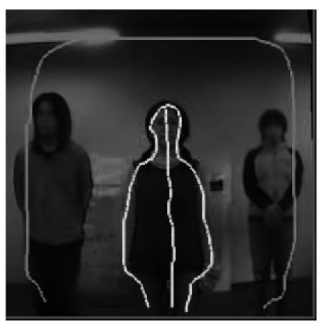

(b)

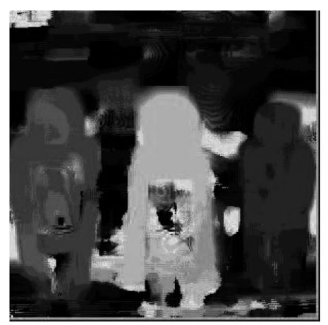

(c)
図 6 前景（白）と背景 (死色) の指定. (a)64 視点画像. (b) 自 由視点画像と (c) その視点位惪で推定された奥行き画像. Assignment of forcground and background secds, depicted as white and gray lines. (a) 64 input images. (b) Freeviewpoint image and (c) its depth map.

用の多視点画像を，オブジェクトのないところに透過処理 を施しながら後ろから順に重㸚ていく.オブジェクトごと に与えるパラメータを制御することで, IP ディスプレイ上 のオブジェクトごとの見え方を操作寸ることができる.

\section{4. 実 験 結 果}

\section{1 オブジェクトの切り抜き}

実験では, 図 6 のように, 中央に女性が一人，その右後 方と左後方に男性が一人ずっ立っているシーンの映像を使 用した。図 6 では中央の人物を切り抜くために，[f]キーを 押してから，自由視点画像上 (図6(b)) で切り抜きたい才 ブジェクトをマウスでドラッグし，その後，[b] キーを押し てから，背景をドラッグすることにより，自由視点画像上 で中央の人物を前景，それ以外を背景として指定している. このように指定した自由視点画像上の点は, その視点位置 で推定されている奥行き情報（図 6(c)）をもとに，64 視点 画像上に即座に反映される。図 6(a)(b)において, 白線は 前景に対して与えた seed を, 灰色の線は背景に対して与 えた seed を表している. 前景と背景の seed を決定した後 に 64 視点画像それぞれにおいてセグメンテーションを行 う. 図 7 は，オブジェクトの切り抜きを行った結果である. セグメンテーションがうまくいかなかった画像については, 3.1 節で述べたように，一つ一つの画像に対して前景と後 景の seed を個別に指定し，セグメンテーションを行った. 


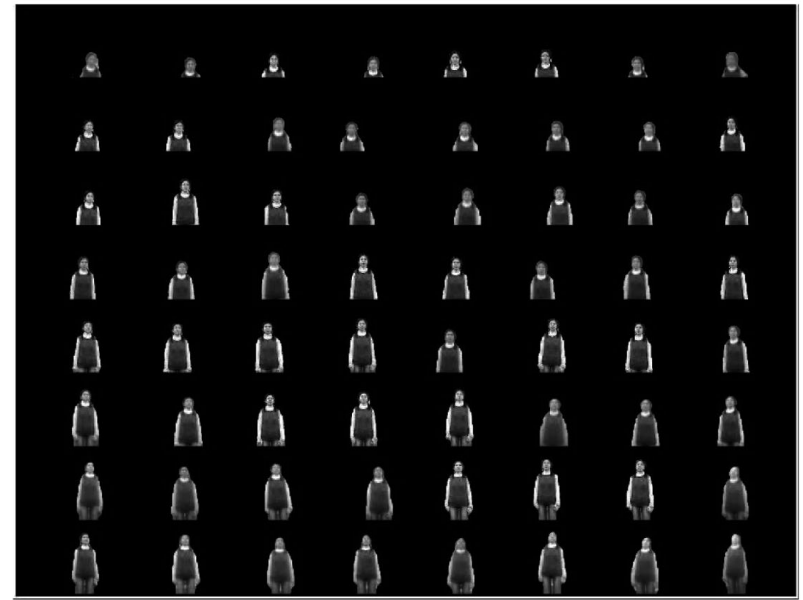

(a)

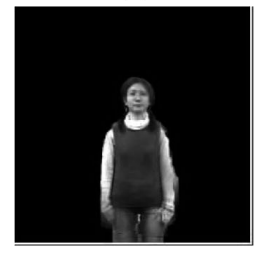

(b)

図 7 オブジェクトの切り拔き結果. (a) 64 視点画像. (b) 合 成丒像.

Result of object extraction. (a) 64 input images. (b) Synthesized image.

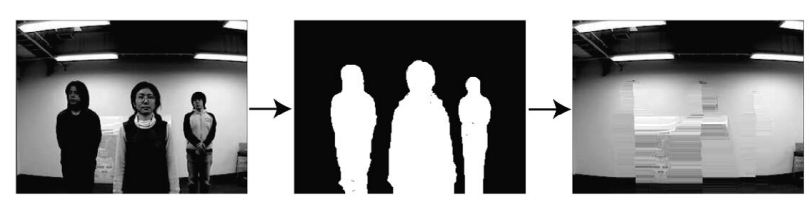

図 8 背景画像の生成

Background image generation.

このようなセグメンテーションを切り抜きたいオブジェ クトの数だけ繰り返す. オブジェクトを切り抜き終えた後, オブジェクトのない背景画像については, 図 8 のように, 切り抜かれた部分の左右の画素值を用いて簡易な補間を行 う.これは, IP ディスプレイ上でオブジェクトの位置を操 作した際，背景に穴があいてしまうことを防ぎ，見えの品 質を向上させるためである。

\section{2 画像合成手法の比較}

切り抜いたオブジェクトのうちの一つに対して, 画像合 成を行った結果を図 9 に示す。図 9 では，2.1節の従来手 法でオブジェクト外の領域を黒とみなして合成を行った画 像と, 提案手法における式 (3) の $P$ の值を 0 と一定の正の 值（800, 実験的に決定）にして合成を行った画像を比較 している. 図 9(a) では, 切り抜いたオブジェクトのエッジ 部分に背景の黒が滑らかに混じっている.これは, 色の補 閒時に背景の黒にも重みをつけて足してしまうためである. 提案手法で $P$ を 0 とした場合には，オブジェクトを通過す る光線のみで分散值を計算することに相当する.この場合, 図 9(b)のように，オブジェクトの外側に間違った色が合成 されてしまう。これは, この領域では参照光線数が 1 とな

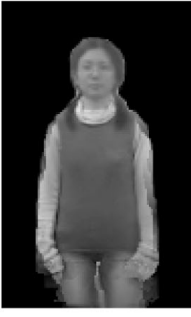

(a) Conventional

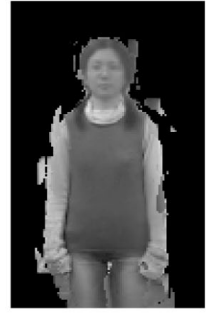

(b) Proposed method (c) Proposed method with $\mathrm{P}=0$

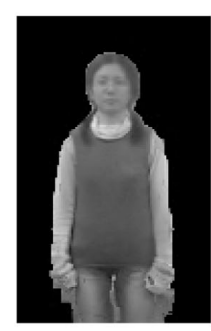

with $\mathrm{P}>0$
図 9 画像合成手法の比較（合成画像の拡大図）。

Comparison of rendering methods (close-up views).

る奥行きレイヤが存在し，その奥行きレイヤで式 (3) のコ ストが 0 となるため, その奥行きに対応する参照光線が色 の補間に利用されるためである*。一方，提案手法で $P$ を 一定值とした場合，光線数が少ない場合にコストを足すこ とでその優先度が下がり, 図 9(c) のように切り抜いたオブ ジェクトは理想的なオブジェクトに近いものとなる.

\subsection{IP ディスプレイへの提示}

以上の過程から作成したオブジェクトごとの 60 視点画 像を IP 画像に変換し，IPディスプレイに表示した結果を 図 10 に示す.ここでは，レンダリングカメラの輻輳面と 位置をオブジェクトごとに独立に制御した．レンダリング カメラの前後方向の位置は輻輳面と同距離だけ動かしてい る. 図 10(a) は, 従来手法通りシーン全体に対して一つの パラメータを用いた場合の表示である．輻輳面の位置は左 の人物の位置（中央の人物の後方, 右側の人物の前方） と した，図 10(b) では，中央の人物の飛び出しを強調するた め，中央の人物に対するレンダリングカメラの位置を前方 (オブジェクトに近づける方向）にずらし, 図 10(a) のとき よりも輻輳面が奥になるようにしている.これにより，中 央の人物がよりディスプレイ面の手前に大きく表示される ようになり，観察者が左右に動いたときのオブジェクトの 移動量（視差）も大きくなっている. 図 10(c) では，前に いた人物を後ろに, 後ろにいた両端の人物二人を前に出し, 奥行き関係を逆転させている，中央の人物に対する輻輳面 をオブジェクトの位置より前にし，両端の人物に対する輻 輳面をオブジェクトの位置よりも後るにすることで, 視点 を左右に動かしたときのオブジェクトの動き方がすべて図 10(b) と逆転する. 図 10(d) では, レンダリングカメラを左 右にずらすことにより，三人の横方向の距離を縮めている.

図 10(c) からわかるように, レンダリングカメラを前方 に動かすと画像の縁に近いオブジェクトほど，より大きく外 力向一移動する（例えば，図 10(c) で左側の人物は図 10(a) よりも左に表示されている）。オブジェクトの位置を変化 させずに前後方向に動かしたい場合には，図 10(d) のよう な水平方向の移動を組合せることが考えられる.

*このノイズが現れている領域とオブジェクトの間では，各墺行きレイヤ における参照光線数が 0 もしくは 2 以上となり, その場合は光線数 0 の奥行きレイヤが選択されるため, 合成される光線の色は黒となる. 


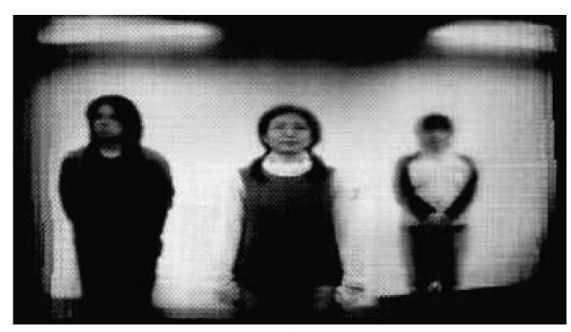

(a)-left

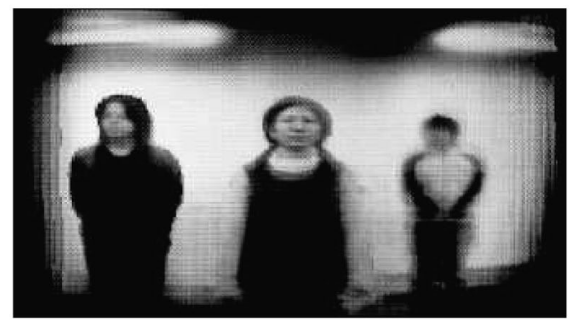

(b)-left

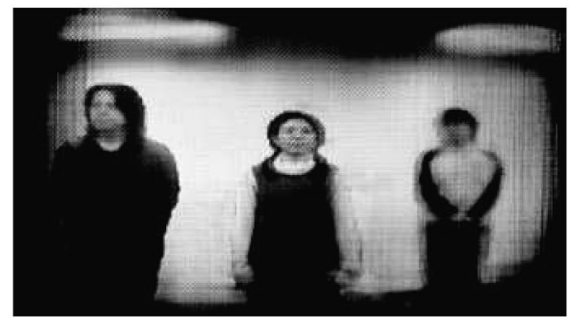

(c)-left

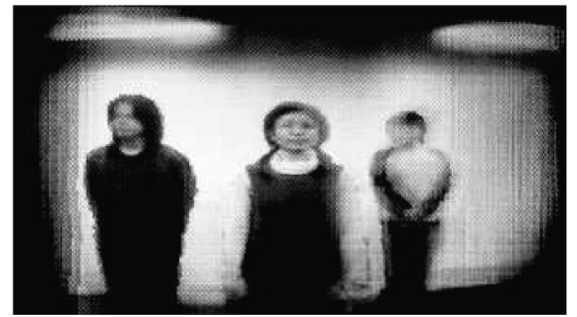

(d)-left

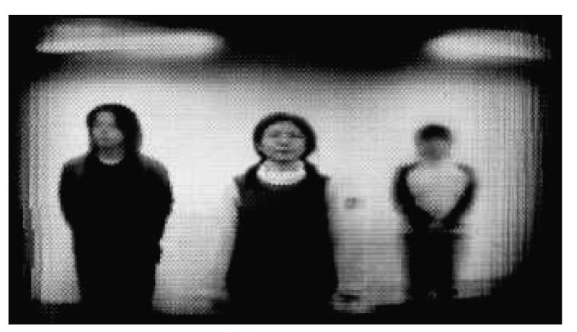

(a)-center

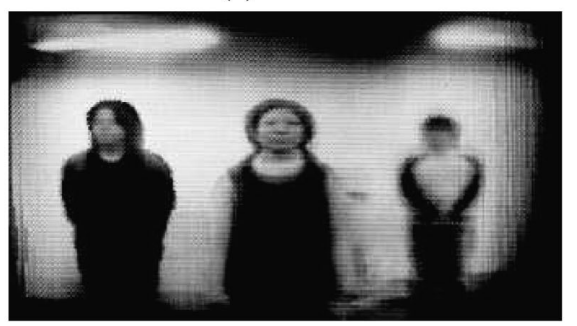

(b)-center

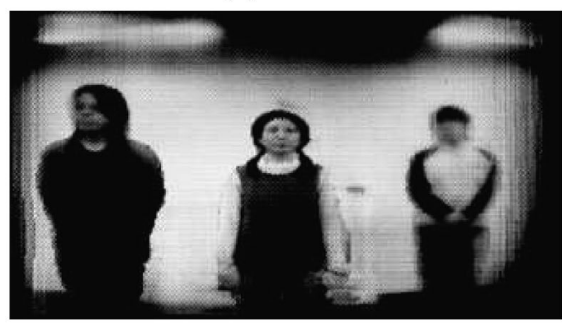

(c)-center

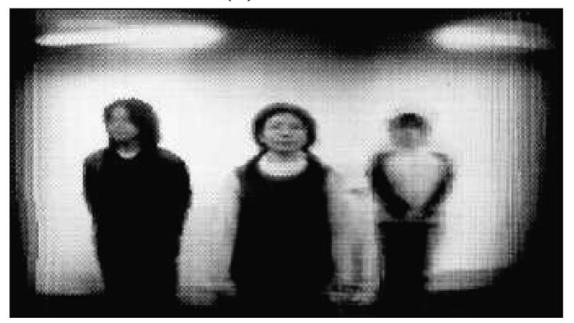

(d)-center

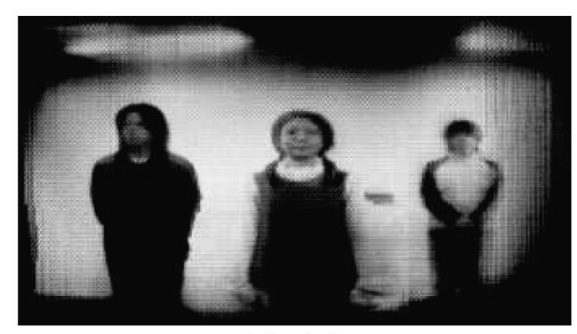

(a)-right

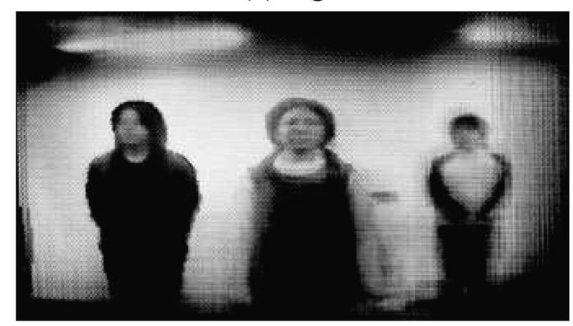

(b)-right

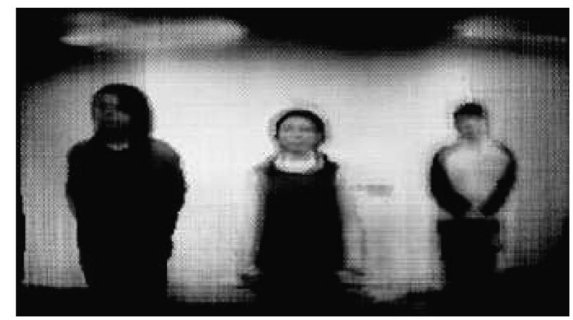

(c)-right

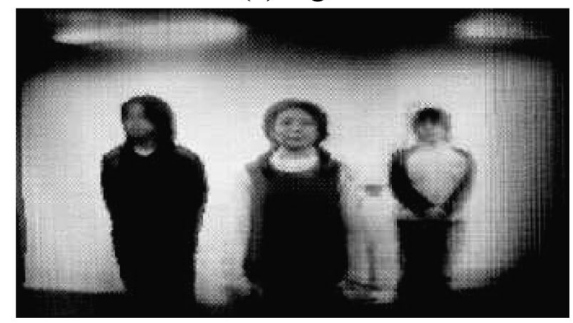

(d)-right

図 10 IP ディスプレイ上での表示結果（左から順に左，中央，右の視点位置から撮影）。(a) シーン全休を一つの パラメータで合成 (従来手法)。(b) 中央の人物を手前に強調して表示. (c) 中央の人物を奥に, 左右の人物 を手前に移動し表示. (d) 三人の水平位置を近づけて表示.

Displayed results captured from a left, center, and right viewpoint. (a) Use a single parameter for the entire scene (conventional). (b) Emphasize the depth of the center person. (c) Move the center person to the back and the left and right persons to the front. (d) Make the horizontal positions close.

図 11 はより複雑なシーンに対して提案手法を適用し, IP ディスプレイに表示した結果である。ここでは，手に風船 を持った右側の人物を切り抜き，パラメータの操作を行っ ている. 図 11(b) では, レンダリングカメラをオブジェク トに近づけることにより，飛び出しを強調している．ただ し，上で述べたように，この場合オブジェクトがディスプ レイの外側 (右側) へ移動している. 図11(c) では，それ を補正するために，レンダリングカメラの水平位置をずら すことで，オブジェクトの水平位置を図 11(a)の場合と同 程度に保ちつつ, 前後方向の飛び出しを強調している.

以上の結果は，画像合成時の奥行きレイヤの枚数を 5 と したとき, 2 frames/second 程度での表示が可能であった. このように, 本手法ではオブジェクトの切り抜きはオフラ インで行うが, 切り抜いたオブジェクトの位置操作はイン タラリティブに実行することができる. また, 図 11 で示し
たように，提案手法ではすべてのオブジェクトを切り抜く 必要はない. 切り抜かれなかったオブジェクトについては, 従来手法と同じ 3 次元的位置で表示され, 切り抜いたオブ ジェクトのみの 3 次元的な位置操作をすることができる.

\section{5.むすび}

本稿では, 裸眼立体映像システムにおけるシーンの編集 を目的として, オブジェクトの 3 次元的な見え方を独立に 操作する手法について検討した。 これを実現するため, カメ ラアレイシステムから得られた多視点画像上で同一のオブ ジェクトを一括して切り抜く手法と, 切り抜いたオブジェク トごとに独立したパラメータを用いて画像合成を行い, IP ディスプレイに立体映像として提示する手法を提案した.

提案手法の問題点としては, オブジェクトの切り抜きの 際, オクルージョンや推定されている奥行き值のエラーに 


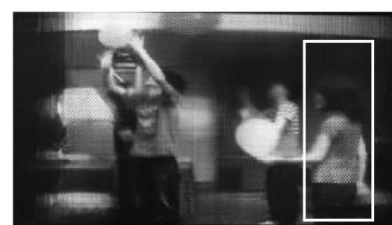

(a)-left

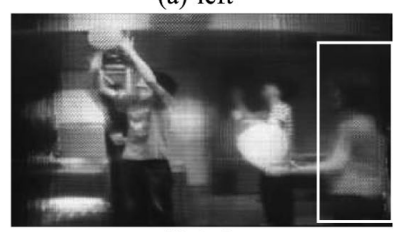

(b)-left

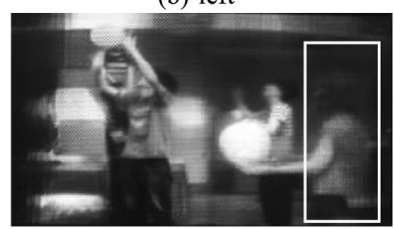

(c)-left

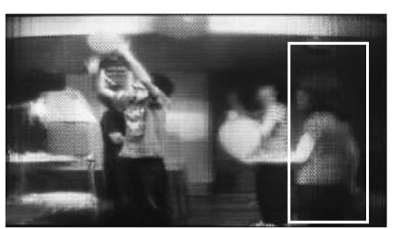

(a)-right

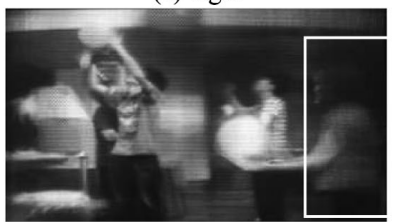

(b)-right

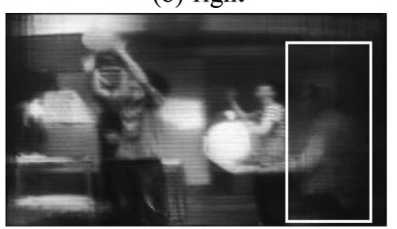

(c)-right
図 11 複雑なシーンの表示結果 (左と右の視点位置から撮影).

(a) シーン全体を一つのパラメータで合成（従来手法）.

(b) 右の人物を手前に強調して表示. (c) さらに水平位 置の補正をした場合.

Display result of a complex scene captured from a left and right viewpoint. (a) Use a single parameter for the entire scene (conventional). (b) Emphasize the depth of the right person and (c) adjust the horizontal position.

よる影響から，前景，背景に指定した seed が意図したも のとは異なることがあり，その場合セグメンテーションを 正しく行うことができないことが挙げられる. 特に, 自由 視点画像の視点位置から離れた視点位置では, この問題が 顕著になる. 現在は入力多視点画像に対して一つの自由視 点画像のみを利用しているが, 多視点画像をいくつかのブ ロックに分け，そのそれぞれについて別々の自由視点画像 を用いて seed を与えるなどの解決策が考えられる. また, セグメンテーション自体の精度を上げるため, 各画像に対 して独立にセグメンテーションを行うのではなく, 奥行き 情報などの画像間の関係をセグメンテーションの尤度の定 義に含めることが考えられる.さらに，静止画だけでなく 動画に対しても同様の操作を行えるようにすることが今後 の課題である.

最後に, 有益なご助言を頂いた, 東京大学の原島博教授, 高橋桂太氏, 小池崇文氏, IP ディスプレイを提供していた だいた株式会社日立ディスプレイズに感謝いたします.

\section{[文献]}

1) A. Kubota, A. Smolic, M. Magnor, M. Tanimoto, T. Chen, and C. Zhang: "Multiview Imaging and 3DTV," IEEE Signal Processing Mag., 24, 6, pp. 10-21 (Nov. 2007)

2) J. Konrad and M. Halle: "3-D Displays and Signal Processing," IEEE Signal Processing Mag., 24, 6, pp. 97-111 (Nov. 2007)

3）田口, 山本, 小池, 高橋, 苗村: “カメラアレイからインテグラルフォトグ ラフィディスプレイへのインタラクティブな 3 次元映像提示”, 3 次元 画像コンファレンス 2008, pp.121-124 (July 2008)

4) Y. Taguchi, T. Koike, K. Takahashi, and T. Naemura: "TransCAIP: Live Transmission of Light Field from a Camera Array to an Integral Photography Display," ACM SIGGRAPH ASIA 2008 Emerging Technologies (Dec. 2008)

5) Y. Taguchi, T. Koike, K. Takahashi, and T. Naemura: "Tran-
sCAIP: A Live 3D TV System Using a Camera Array and an Integral Photography Display with Interactive Control of Viewing Parameters," IEEE Trans. Visual. Comput. Graphics (to appear)

6) H. Hoshino, F. Okano, H. Isono, and I. Yuyama: "Analysis of Resolution Limitation of Integral Photography," J. Opt. Soc. Am. A, 15, 8, pp. 2059-2065 (Aug. 1998)

7) M. Zwicker, A. Vetro, S. Yea, W. Matusik, H. Pfister, and F. Durand: "Resampling, Antialiasing, and Compression in Multiview 3-D displays," IEEE Signal Processing Mag., 24, 6, pp. 88-96 (Nov. 2007)

8) F. Okano, J. Arai, H. Hoshino, and I. Yuyama: "ThreeDimensional Video System Based on Integral Photography," Opt. Eng., 38, 6, pp. 1072-1077 (June 1999)

9) W. Matusik and H. Pfister: "3D TV: A Scalable System for RealTime Acquisition, Transmission, and Autostereoscopic Display of Dynamic Scenes," ACM Trans. Graphics, 23, 3, pp. 814-824 (Aug. 2004)

10）田口, 高橋, 苗村: “ネットワークカメラアレイを用いた実時間全焦点自 由視点映像合成システム”, 情処研報, CVIM-162-14, pp.79-86 (Mar. 2008)

11) T. Koike, M. Oikawa, K. Utsugi, M. Kobayashi, and M. Yamasaki: "Autostereoscopic Display with 60 Ray Directions using LCD with Optimized Color Filter Layout," Proc. SPIE SD\&A XVIII, 6490A (Mar. 2007)

12) Y. Boykov and M-P. Jolly: "Interacive Graph Cuts for Optimal Boundary \& Region Segmentation of Objects in N-D images," Proc. IEEE ICCV 2001, I, pp. 105-112 (July 2001)

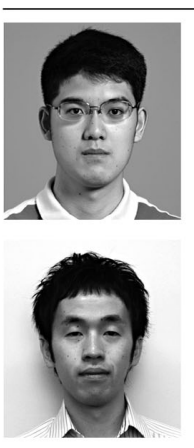

なが塚 遼 2009 年, 東京大学工学部電子情報工 学科卒業. 現在, 同大学大学院情報理工学系研究科修士 課程在学中. 空間共有通信に関寸る研究に従事.

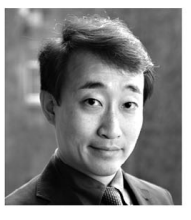

たぐ思口虫うん 2004 年, 東京大学工学部電子情報工学 科卒業. 2009 年, 同大学大学院情報理工学系研究科博士 課程修了. 現在, Mitsubishi Electric Research Laboratories 博士研究員. 3 次元画像処理と符号化に関する 研究に従事. 博士 (情報理工学).

な离㽦村 健 1997 年, 東京大学工学部電子工学科 卒業, 博士課程修了. 米国久タンフォード大学客員助教 授 (日本学術振興会海外特別研究員) を経て, 現在, 東 京大学情報理工学系研究科電子情報学専攻, 准教授 (学 際情報学府兼担)。メディア+コンテンツ，実世界指向情 報環境, 空間共有通信などの研究に従事. 博士 (工学). 正会員. 